\title{
Analysis of the Influence of Inflation and Interest Rates on Stock Price (Case Study at PT Bank Mega, Tbk for the Period 2005-2011)
}

\author{
Mohamad Irfan \\ Padjajaran University, Bandung, Indonesia \\ \{aabrahma66@gmail.com\}
}

\begin{abstract}
This study aims to determine whether there is a significant reciprocal relationship between inflation with interest rate of Bank Indonesia Certificates (SBI) and between with stock price PT. Bank Mega Tbk. The technique at this research is used multiple linier regression with variable independent inflation and interest (SBI) look forwards dependent variable stock price. Research methods used multiple linear regression analysis, test $t$ and test f. Dependent variable from this study is the stock price of PT. Bank Mega Tbk. Results of this study indicate there is significant influence relationship between inflation with interest rate of Bank Indonesia Certificates (SBI) against stock price PT. Bank Mega Tbk.
\end{abstract}

Keywords: Stock Price, Inflation, Bank Indonesia Certificates (SBI)

\section{Introduction}

As important instruments in the macro economy: inflation, interest rates, also the exchange rate (foreign exchange) or the amount of money in circulation that will fluctuate will certainly affect investment activities as an important variable supporting economic growth. The occurrence of inflation, for example, will affect investment in the goods market, this is due to people's demand for goods and services continues to increase. The relative increase in inflation is a negative signal for investors, high inflation causes a decline in the profitability of a company so that it will reduce the company's dividend happiness for shareholders and in turn can reduce people's purchasing power. Likewise, if interest rates on Bank Indonesia Certificates (SBI) increase, it can have an impact on increasing deposit rates, which in turn results in high lending rates, resulting in a declining investment climate in the economy. Declining domestic investment results in a deteriorating domestic economy due to investor confidence domestic and foreign countries are also eroded for example investment in the capital market.

The capital market functions to trade securities such as bonds and stocks issued by the government, public authorities and private companies for the short and long term. In the capital market that is traded is a security which is a piece of paper that shows the right of the investor, that is the owner of the paper has the right to obtain a share of the prospect or wealth of the organization that issued the security. In this case, investors who are very concerned about the high return of the securities to be bought, for that investors usually always apply a portfolio investment strategy. Like the capital market, the banking industry as a financial institution has an important role in the development and economic growth of a country. According to Goldstein (1998: 56) and Nugroho (2000: 45) that the national banking industry is one of the economic sectors in Indonesia that is vulnerable to shocks and changes in the economic cycle. Therefore a healthy banking system is needed as a prerequisite for a good economy. The selection of the 
banking sector as a population in this study because banking is generally very sensitive to changes in macroeconomic variables, besides that changes in internal variables are also always a public concern, especially for banking businesses that have gone public. Choosing PT Bank Mega Tbk as a company The object of the research is that the company is a banking company that has gone public. On the other hand, the bank mentioned above is a bank that has a fairly good performance at this time, in addition, during the study period, it showed good performance and soundness.

The scope of this research is to try to measure the level of significance of macroeconomic influence in this case the effect of inflation and interest rates on Bank Indonesia Certificates on the banking industry in PT Bank Mega Tbk shares listed on the Indonesia Stock Exchange (BEI) with the consideration that banking shares are one of the the source of investment in the financial market and is a sector that experiences a direct impact of changes in macroeconomic variables, especially those related to the choice of the investor community in investing. This is supported by statements from analysts.

Based on the background of the problems mentioned above, the following problems can be identified: That external factors originating from outside the company such as inflation rates, interest rates on Bank Indonesia Certificates (SBI) that can increase or even decrease general economic conditions affect conditions and corporate securities that socialized through the capital market, and in addition to company internal factors that can affect the condition and securities of the company. Through the identification of the problems mentioned above, the following research problems can be formulated: Does the level of inflation and interest rates of Bank Indonesia simultaneously affect the stock price of PT. Bank Mega, Tbk. Does the inflation rate partially affect the stock price of PT. Bank Mega Tbk. Is it partially the interest rate of Bank Indonesia Certificates affect the stock price of PT. Bank Mega, Tbk.

This research is expected to provide a more definite and more scientific answer about various factors that influence fluctuations in the company's stock price on the exchange from 20052011. The results are expected to provide the right answers about various factors that influence fluctuations in stock prices on the stock exchange. In theory, external factors such as the sensitivity of changes in macroeconomic variables are very influential on changes in the company's stock price in the market. To prove this theory, a study of the company's stock price of PT. Bank Mega Tbk. This study aims to: Analyze the simultaneous effect of inflation rates and interest rates on Bank Indonesia certificates on the stock price of PT. Bank Mega Tbk. Analyzing the effect of partial inflation on the stock price of PT. Bank Mega Tbk. Analyzing the effect of partial interest rates on Bank Indonesia certificates on the stock price of PT. Bank Mega Tbk. From the data obtained and from the results of the data processing will be proven and analyzed the relationship of the company's external factors to the company's stock price by the OLS (ordinare least squares) method.

From the results of the analysis will be seen which external factors are the most dominant influence on changes in the company's stock price, and the extent to which the company can utilize these factors to increase the company's selling value. The results of this research are expected to be useful and make a significant contribution to the development of knowledge, especially related to financial management. In addition, the results of this study are also expected to be a reference for subsequent studies interested in the same field. This research is expected to provide information about which macroeconomic external variables which have the greatest influence on the development of PT. Bank Mega Tbk on the Indonesia Stock Exchange. 


\section{Literature Review}

According to Hartono (2000: 107) Capital market instruments in principle are all securities (securities) commonly traded through the capital market. Securities are any debt recognition instruments, commercial securities, shares, bonds, credit securities, debt proofs, rights, warrants, options or any derivatives of securities or any instruments determined by Bapepam as securities. Nature of securities traded on the market capital (the Stock Exchange) is usually longterm. The most common instruments traded through the Stock Exchange in Indonesia today are stocks, bonds, and rights. Stocks are proof of ownership of capital in a limited liability company. In buying and selling transactions on the Stock Exchange, shares or often also in call shared is the most dominant instrument in trading. The shares can be issued by way of the name or performance. Furthermore, the shares can be distinguished between common shares and preferred stocks.

Based on Law No. 7/1992 (as amended by Law No. 10/1998) concerning banking, banks are defined as business entities that collect funds from the public in the form of savings and distribute them to the public in the form of credit or other forms. The law classifies banks into two groups, namely Commercial Banks and Rural Credit Banks (BPR). Inflation is the tendency of prices for goods and services including factors of production, measured in units of currency, which are increasingly rising in general and continuously (Na'im, 1995: 1). Meanwhile, according to Nopirin (2000: 25) Inflation is the process of increasing the general prices of goods continuously. The inflation rate is called positive, if the price increases. Conversely, if prices decline, the inflation rate is called negative. According to the theory of inflation occurs because people have demand exceeds the amount of money available. In his theory, Keynes states that inflation occurs because people want to live beyond their economic capacity. The process of fighting for sustenance among the community still raises aggregate demand (overall) that is greater than the amount of goods available, causing prices to generally rise. If this continues, so long as the inflation process will take place.

Interest rates according to Khalwaty (2000: 145) are conventional instruments to control or reduce the rate of inflation growth. High interest rates will encourage people to invest their funds in banks rather than investing them in other sectors that are more risky. High interest rates can suck up money circulating in the community. The money supply can affect the stock price index through two channels, namely directly and indirectly. Directly through the capital market approach (Asset Market Approach), where if there is an increase in the money supply, the investor community will increase the proportion of his wealth in the form of securities so that demand for shares has increased. Interest rates (SBI) reflect how an investor invests his money in the money market and how it affects the stock price index. If there is an increase in interest rates, the investor community is more likely to invest in deposits and savings with a higher return than investing in securities. The transfer of investment allocation from portfolio to time deposits causes demand for securities to decline, thereby causing the stock index to decline.

Bank Indonesia Certificates (SBI) are one that can be used by Bank Indonesia as a means of controlling rupiah stability. Bank Indonesia Certificates (SBI) are short-term rupiah debt instruments. In the first stage, the SBI period is set at 30 days and 90 days. For each of these periods, SBI was issued in the first phase with their respective denominations: Rp. 50 million, Rp. 250 million and Rp. 1 billion. The interest rates that apply to each SBI sale are determined by market mechanisms based on the auction system. In this case banks will buy the bonds, where the Central Bank will offer high SBI interest rates, thereby causing bank liquidity to decrease. To increase the level of liquidity, banks compete to get the maximum amount of funds from the public by increasing deposit rates, namely deposit rates (Dwiastuti, 2006). 
Research on earnings management (earnings management) is also not a little done by previous researchers. Some of these studies are: Tendi Haruman et al (2005) investigating the influence of macroeconomic fundamentals and systematic risk on stock returns on the JSX, showing that EPS, PER, exchange rates and beta variables have significant positive direction coefficients while inflation rates have significant negative directional coefficients where all These variables have an effect both partially and jointly on the level of individual stock returns. Jalu (2004) in his research on the analysis of the influence of factors affecting foreign exchange demand in Indonesia after the 1999-2002 economic crisis. The method used in the ECM (Error Correction Model) study, the results showed that foreign exchange demand in Indonesia was largely influenced by the magnitude the level of magnitude of imports of goods, both changes and previous periods. The magnitude of the coefficient of influence sequentially 0.348 and 0.571 in addition to changes in deposit rates also affect demand for foreign exchange with a coefficient value of -0.24. the model is normal. Aurzzi and Bandi (2003) examine the effect of interest rates, profitability ratios and accounting beta on sharia stock beta. The sample of this research is companies listed on the Jakarta Stock Exchange which are included in the Jakarta Islamic Index (JII). There are 30 companies that are sampled. Rustam Hidayat (2001) examines the effect of market returns, inflation rates, deposit rates, gold prices, net national income and exchange rates on stock returns, showing that market returns, inflation rates, deposit rates, the price of gold has a significant effect on returns, while the net national income and the exchange rate have no significant effect on stock returns.

Thinking Framework in this study that the stock price is the market price of a listed stock every day. Jogiyanto (2003) argues that stock prices are a reflection of the value of a stock. The size of the stock price when sold on the primary market is different from the share price on the secondary market. The price of shares in the primary market is determined based on an agreement between the issuer and underwriter, while the price of shares in the secondary market is determined by the market mechanism (demand and supply) and fluctuates based on changes in public valuation of the company's shares. The valuation of the community itself changes with changes in factors that influence the formation of stock prices, for example government policies, economic conditions, or the financial performance of the company itself.

According to Lipsey, Ragan, Courant (1997: 368), inflation is an increase in the average level of all prices. The inflation rate is called positive, if the price increases. Conversely, if prices decline, the inflation rate is called negative. According to Case (2001: 425), inflation is the increase in the price of all goods and services in a certain period of time. High inflation rates cause monetary restrictions that lead to high interest rates, causing long-term bond prices and stocks to be lower. Because interest rates become high, the price of bonds that have been previously issued at a low price will fall in price, and share prices will be lower because capital owners are more interested in investing their capital in the form of deposits or bonds offering higher interest rates. This study examines the relationship and influence of inflation and interest rates on Bank Indonesia Certificates on stock price fluctuations. This phenomenon can be designed through the following mathematical functions: $\hat{Y}=F(X 1, X 2,+X n)$ multivariate equation model, and $\hat{Y}$ $=\mathrm{F}(\mathrm{X})$ for the bivariate equation model. Specifically, this research design can be written in a mathematical formula as follows:

a) Simultaneous relationship between independent variable X1 (inflation) and independent variable X2 (interest rate) on the dependent variable Y (share price) can be formulated with model 1 (one), namely: 


$$
\begin{aligned}
& \mathrm{Y}=\mathrm{f} \square \mathrm{X}_{1} \square \\
& \mathrm{Y}^{\wedge}=\mathrm{a} \square \mathrm{b}_{1} \mathrm{X}_{1} \square \mathrm{b}_{2} \mathrm{X}_{2} \square \mathrm{e}
\end{aligned}
$$

b) Partial relationship between the independent variable X1 (inflation rate) to $\mathrm{Y}$ (share price) can be formulated with model 2 (two), namely:

$\mathrm{Y}=\mathrm{f} \square \mathrm{X}_{1} \square$

predicted as:

$\hat{\mathrm{Y}^{\wedge}}=\mathrm{a} \square \mathrm{b}_{1} \mathrm{X}_{1} \square \mathrm{e}$

c) Partial relationship between the independent variable X2 (interest rate) to $\mathrm{Y}$ (share price) can be formulated with model 3 (three), namely:

$\mathrm{Y}=\mathrm{f} \square \mathrm{X}_{2} \square$

predicted as:

$\hat{\mathrm{Y}}=\mathrm{a} \square \mathrm{b}_{2} \mathrm{X}_{2} \square \mathrm{e}$

The design models described above can be illustrated in chart 1 below:

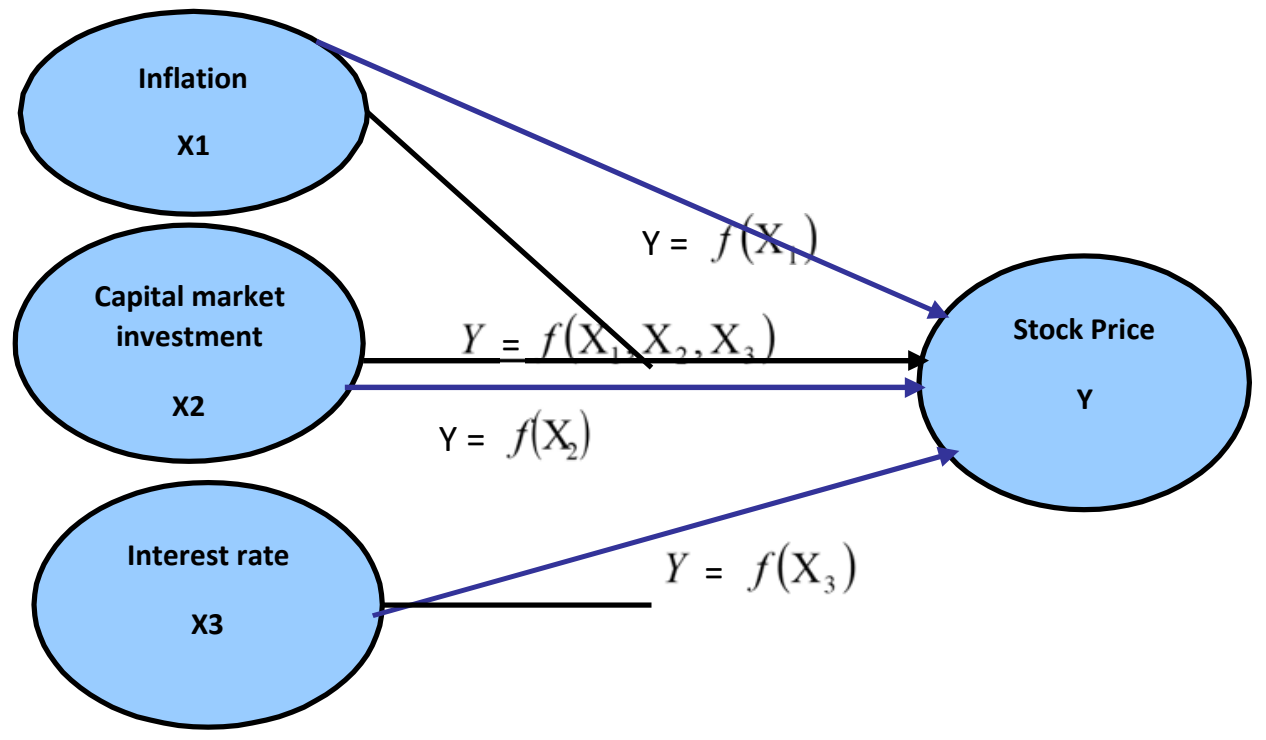

From this framework, the following hypotheses can be explained: Inflation and interest rates of Bank Indonesia Certificates (SBI) have a significant effect on the stock prices of PT. Bank Mega, Tbk. The level of inflation has a significant effect on the stock prices of PT. Bank Mega, Tbk and the interest rate of Bank Indonesia Certificates (SBI) significantly influence the stock price of PT. Bank Mega, Tbk. 


\section{Research Methods}

In this study, the analysis method used consists of descriptive analysis and quantitative analysis. Descriptive analysis is done by analyzing the development of PT Bank Mega Tbk stock prices, and external variables that influence it. Whereas quantitative analysis is carried out by analyzing the development of macroeconomic variables such as SBI interest rates and inflation rates. bank.By trying to get a proper description of the phenomenon of development and fluctuations in the stock prices of PT Bank Mega Tbk in the period 2005-2011 and try to describe precisely the factors that influence it by looking at which factors are the most dominant. Quantitative data can be based on assumptions and assessments expressed with qualitative data (Sarwono, 2011). Population is a combination of all elements that have a series of characteristics similar to Malhotra (2010: 371).

\section{Analysis}

a) The results of data processing with the SPSS program prove that it turns out that the synergy of variable inflation rates, interest rates on Bank Indonesia Certificates simultaneously can provide a relatively strong, positive and significant contribution to stock prices. The following calculation results are presented:

Table 1. Inflation Bank Indonesia

\begin{tabular}{lcccccc}
\hline \multirow{2}{*}{ Model } & \multicolumn{2}{c}{$\begin{array}{c}\text { Unstandardized } \\
\text { Coefficients }\end{array}$} & \multicolumn{2}{c}{$\begin{array}{c}\text { Standardiz ed } \\
\text { Coefficient s }\end{array}$} & \\
& & B & Std. Error & Beta & t & Sig. \\
\hline 1 & (Constant) & 57.459 & 78.068 & & 4.507 & .000 \\
& Tingkat_Inflasi & 14.841 & 40.852 & .233 & .545 & .015 \\
& Suku_Bunga_S BI & 23.979 & 29.726 & .482 & 1.130 & .022 \\
\hline
\end{tabular}

Dependent Variable: HS Bank Indonesia

b) The results of data processing with the SPSS program prove that it turns out that the synergy of the variable inflation rate is able to make a positive and strong contribution to stock prices. The following calculation results are presented:

Table 2. Inflation Bank Mega

\begin{tabular}{|c|c|c|c|c|c|c|}
\hline & \multicolumn{6}{|c|}{ Coefficients $^{\mathrm{a}}$} \\
\hline & \multirow[t]{2}{*}{ Model } & \multicolumn{2}{|c|}{$\begin{array}{l}\text { Unstandardized } \\
\text { Coefficients }\end{array}$} & \multirow{2}{*}{$\begin{array}{c}\text { Standardiz ed } \\
\text { Coefficient s } \\
\text { Beta }\end{array}$} & \multirow[b]{2}{*}{ t } & \multirow[b]{2}{*}{ Sig. } \\
\hline & & B & Std. Error & & & \\
\hline \multirow[t]{2}{*}{1} & (Constant) & 55.693 & 76.114 & .411 & 8.124 & .000 \\
\hline & Tingkat Inflasi & 52.052 & 56.507 & & 1.007 & .015 \\
\hline
\end{tabular}

a. Dependent Variable: HS_Bank_Mega

c) The results of data processing with the SPSS program prove that it turns out that the 
synergy of variable interest rates on Bank Indonesia Certificates is partially able to make a positive and significant contribution to stock prices. The following calculation results are presented:

Table 3. Interest Rate Bank Indonesia

\begin{tabular}{|c|c|c|c|c|c|c|}
\hline \multicolumn{7}{|c|}{ Coefficients $^{\mathrm{a}}$} \\
\hline & \multirow[t]{2}{*}{ Model } & \multicolumn{2}{|c|}{$\begin{array}{l}\text { Unstandardized } \\
\text { Coefficients }\end{array}$} & \multirow{2}{*}{$\begin{array}{l}\text { Standar dized } \\
\text { Coeffici ents } \\
\text { Beta }\end{array}$} & \multirow[b]{2}{*}{$\mathbf{t}$} & \multirow[b]{2}{*}{ Sig. } \\
\hline & & B & Std. Error & & & \\
\hline \multirow[t]{2}{*}{1} & (Constant) & 56.184 & 14.017 & .568 & 4.860 & .000 \\
\hline & Suku_Bunga_SBI & 46.024 & 64.563 & & 1.544 & .022 \\
\hline
\end{tabular}

a. Dependent Variable: HS_Bank_Mega

\section{Conclusion}

After conducting research the author tries to conclude, that: Simultaneously the Inflation Rate and Interest Rates of Bank Indonesia Certificates have a positive and significant effect on stock prices, it can be explained, that simultaneously these two variables are able to predict a positive influence, and are also able to contribute strong relative to linear changes in stock prices, note $\mathrm{R}$-square $(\mathrm{R}$ square $=0.475$ with an estimated residual that is explaned residual or equal to $(475,8081)$. Partially the level of inflation towards stock prices, can be explained that partially the variable is able to predict positive influence, and also able to contribute relatively strong to linear changes in stock prices, pay attention to R-square ( $\mathrm{R}$ square $=0.469$ with estimated residuals that are explaned residuals or 488.7947). Partially, Bank Indonesia Certificate Interest Rates on stock prices, can be explained that partially these variables are able to predict a positive influence, and can also contribute relatively strongly to linear changes in stock prices, pay attention ( $\mathrm{R}$ square $=0.523$ with estimated residuals the explaned residual or equal to 441,10511).

\section{References}

[1] Calantone, R. J. di Bennedetto, C.A dan Divine, R. 1993.Organisasional, Technical and Marketing Antecedents or Succsesfull New Product Development. R\&D Management Journal.

[2] Fengki Octora Kurniawan. 2005. Analisis Faktor-faktor yang Mempengaruhi Keunggulan Bersaing Produk Terhadap Kinerja Penjualan ( Studi Pada Industri Manufaktur di Semarang ). Jurnal Sains Pemasaran Indonesia. Vol. IV, No.1 : 17-30, Mei 2005

[3] Hayes, R.H. dan Schmenner, R.W. 1978 How Should you Organize Manufacturing ?. Harvard Business Review, Vol.56 No.1

[4] Hunger, J. David \& Thomas I. Wheelen.2015. Manajemen Strategis. Andi Publisher, Yogyakarta. Hossain . A. Chowdry.1998. Open Economy Macroeconomics for Developing Counttries..

[5] Edward Elgar Publishing Limited, United Kingdom.

[6] Kotler, Philip. 1997. Manajemen Pemasaran : Analisis Perencanaan, Implementasi dan kontrol. Edisi Bahasa Indonesia.

[7] Lind,2002. Basic Financial Management: Dasar-dasar Manajemen Keuangan. Raja Grafindo Persada, Jakarta.

[8] Malholtra ,2010, Empirical Research in Software Engineering: Concepts, Analysis, and Applications.Taylor \& Francis Group, New York.

[9] M. Fanshurullah Asa, Ismeth S. Abidin, Yusuf Latief. 2008. Faktor-Faktor Kritis dalam Sistem 
Manajemen Mutu ( SMM ) untuk Optimasi Profitabilitas dan Daya Saing Perusahaan Jasa Konstruksi di Indonesia. Jurnal Teoritis dan Terapan Bidang Rekayasa Sipil. Desember 2008.Vol. 15 No. 3 : 99-106

[10] Mankiw, Gregory N.2000. Teori Makro Ekonomi, Penerbit Erlangga, Jakarta [11] Nugroho, A.E.2000. Industri Perbankan dan Keuangan Nasional. PEP-LIPI. Jakarta

[12] Nopirin, A.1992.Ekonomi Moneter, Edisi ke 4. BPFE Yogyakarta Negara, S.2001. Kinerja Pasar Modal Indonesia.PEP-LIPI, Jakarta

[13] Peraturan Bank Indonesia 2004. Penilaian Tingkat Kesehatan Bank.No.6/10/PBI/2004. Bank Indonesia Jakarta

[14] PT. Bank Mega Tbk.2011. Laporan Tahunan PT. Bank Mega, Jakarta.

[15] PT. Indonesian Cappital Market Electronic Library 2013, Bursa Efek Jakarta, Jakarta.

[16] Rindjin, K 2000. Pengantar Perbankan dan Lembaga Keuangan.Gramedia Pustaka Utama, Jakarta. Sarwono, Jonathan. Strategi Melakukan Riset Kuantitatif, Kualitatif, dan Gabungan. Andi Publisher, Yogyakarta.

[17] Warijo, Perry.2004. Bank Indonesia: Bank Sentral Republik Indonesia. Pusat Pendidikan dan Studi Kebanksentralan, Jakarta.

[18] Wiranta, S.2001.Kebijakan Suku Bunga sebagai sasaran antara untuk mempengaruhi Inflasi, Jakarta. 